\title{
A HATÉKONY VÁLSÁGKOMMUNIKÁCIÓ
}

A szerző dolgozatában a válságkommunikáció folyamatát mutatja be. Elemzi a folyamatban résztvevők feladatait, azok sajátosságait. Feltárja azokat a vezetői készségeket, képességeket, melyek nélkülözhetetlenek a sikeres válságmegoldáshoz.

A válságnak többféle meghatározásával találkozhatunk a szakirodalomban, amelyek többé-kevésbé lefedik egymást.

„Tág értelemben a válság olyan - a társadalmakkal, gazdasági rendszerekkel, szervezetekkel és emberekkel kapcsolatos - folyamat, amelynek lezajlása során az érintett emberek, szervezetek, rendszerek, társadalmak működése - súlyosabb esetekben fennmaradása is - közvetlen veszélybe kerülhet." 1

„Nehéz, veszélyes helyzetet és olyan időszakot fejez ki, amelyben viszonylag gyorsan, határozottan és fordulatot elérő szándékkal dönteni kell.”2

Ami bizonyos az az, hogy a válság:

- súlyos zavar, nehéz helyzet, kellemetlen, nem kívánatos esemény,

- érinthet egyént, csoportot vagy akár az egész társadalmat,

- kimenetele jó és rossz is lehet.

\section{Kommunikáció}

Minden olyan folyamat, amikor információ-átadás történik, függetlenül attól, hogy az információ milyen jelekben, a jelek milyen rendszerében, kódjában jelenik meg.

\section{Válságkommunikáció}

„A válságkommunikáció az a folyamat, amelynek keretében a működési zavar leküzdését szolgáló hírek, üzenetek, információk, vagyis „kommünikék” továbbítása történik.”3 Azaz gyors, hiteles információk átadása, amelyek az adott válsággal, illetve annak kezelésével kapcsolatban keletkeztek.

A válságkezelés és a válságkommunikáció tehát két szorosan összetartozó dolog. A kettő együtt jelenti a szervezet viselkedését az adott helyzetben.

\section{A válságkommunikáció célja}

A válságkommunikáció célja - az egyéb feltételek teljesítése mellett -, hogy a szervezet a kommunikációs csatornákon közvetíteni tudja:

- mi történt, mi a valóságos helyzet, azaz a célközönség által észlelt látszat a lehető legközelebb kerüljön a valósághoz,

(A válsághelyzetek során ugyanis kétféle valóság létezik. Az első, primer valóság, az a kép, ami a szervezetben él, míg a szekunder valóság a tényleges helyzet fogyasztók általi érzékeléséből és a válságkommunikáció során küldött üzenetek részbeni átvételéből, illetve az egyéb forrásokból származó információk alapján áll össze. Ennek a szekunder valóságnak fontos jellemzője, hogy felnagyítja a történéseket és veszélyeket, valamint időbeli szinkronkülönbséggel jelenik meg és ér véget. A primer és a szekunder valóság között helyezkedik el az a kritikus mező, amelyet a válságkommunikációval a lehető legszűkebbre kell csökkentenünk.)

- hogyan szándékozik a válságot megoldani,

- rendelkezik-e a válság felszámolásához szükséges feltételrendszerrel? 


\section{A válságkommunikáció alapelemei}

- Az üzenet forrása (inputja): válságstáb, kódolja az üzenetet.

Mivel a válságok nem a napi vezetési technikákkal menedzselhetők, a lehetséges válsághelyzetekhez illeszkedően előre ki kell jelölni a válságstábot (belső kör). Ennek létszáma nem lehet túl nagy, mert ez az operativitás rovására menne. A válságstáb vezetőjének nem szerencsés az első számú vezetôt választani, ha ez történik, fennáll a veszélye annak, hogy ugyanazokat a hibákat követi el, mint amelyek bajba juttatták a szervezetet. A szervezeti „,vakság” elkerülése miatt előnyös külső szakértők bevonása. A válságstábban egy határozott, irányításra képes vezető mellett az érintett terület menedzsmentjét is célszerű képviseltetni. A PR kérdésekkel foglalkozó munkatársnak és a szóvivőnek - ha van ilyen - is jelen kell lenni a megbeszéléseken. Az így felálló válságmenedzsmentcsapatban ${ }^{4}$ a döntéshozó a válságstáb, a középső körön elhelyezkedők feladatai a pénzügyi, gyártási, termelési, jogi, emberi erőforrás, egészség és biztonsági problémákhoz kapcsolódnak. Ők tanácsadó szerepet kell, hogy betöltsenek. A külső körnek kell kapcsolatot létesítenie a befektetőkkel és a részvényesekkel, és a támogatások, a források megszerzését biztosítania (1.ábra).

1. ábra

\section{Válságmenedzsment-csapat}

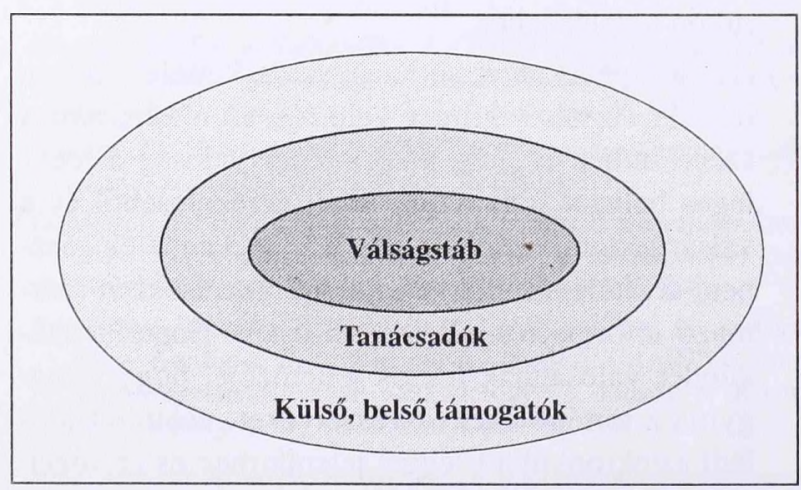

- Az üzenet befogadója (a kommunikációs folyamat outputja): a célközönség.

A válságstábnak tevékenysége során meg kell határoznia a célközönséget, mert a válságkommunikációra általában az a jellemző, hogy nem fedi le pontosan a válsággal érintettek körét (nem mindenkihez jutnak el az üzenetek), másrészt jóval túl- terjed az érintettek körén, vagyis sokkal többen tudnak egy válságos helyzetről, mint ahányan érintettek. A szervezetnek ennek megfelelően kettős feladatot kell ellátnia. Biztosítania kell, hogy lehetőleg minden érintett személy részese legyen a „hivatalos" válságkommunikációnak, és amennyire lehet, meg kell akadályozni, hogy felesleges területekre terjedjen ki. A célközönségen belül célszerű a „véleményvezér" ${ }^{-}$-eket megkülönböztetni. Ők, akik akár pozíciójuknál, akár személyiségüknél fogva befolyással vannak a célközönségre. Megfelelő tájékoztatásukkal komoly segítséget jelenthetnek a válságstábnak.

- A hír, üzenet: a közlés tartalma. (Mi történt? Mit mondjunk? Hogyan mondjuk?) A célközönség ismeretében el kell dönteni, hogy a racionális vagy az emocionális tartalmú üzenettel érjük-e el a kívánt hatást. A szervezeti válságok esetében elsősorban a logikus összefüggéseket bemutató, azaz az értelemhez szóló üzenetekkel érhetjük el a megfelelő eredményt.

- Csatorna: az üzenet valamilyen csatornán keresztül jut el a befogadóhoz. Ez történhet közvetlen módon, amikor egy személy vagy azok csoportja juttatja el az üzenetet a célközönséghez, illetve közvetett módon. Ez utóbbi esetben a közvetítő csatorna valamilyen médium.

- Zaj: a jelhez olyan dolgok is hozzáadódnak, amit az információ küldőjének nem volt szándékában előállítani ${ }^{6}$. Ez a válságkommunikációban olyan nem tervezett torzulás, ami ahhoz vezet, hogy a közönség olyan üzenetet kap, amelynek küldése nem állt a válságstáb szándékában.

A zaj lehet:

- környezeti (maga a helyzet teremti meg),

- csatorna (a közvetítő lánc hibája, például sérült telefonvonal),

- kommunikációs zaj, ami vagy a kódoláskor vagy a dekódoláskor jön létre.

(1)

Kommunikációs zavar: az információcserében érdekelt felek közötti összhang hiánya. Egymás megértése torzul, elmarad, ezáltal a szervezet működésében gondok jelentkeznek. Ilyen probléma nemcsak a válságkommunikáció során keletkezhet (2. ábra).

\section{A válságkommunikáció folyamata}

A válságstáb a saját maga által kialakított üzenetet kódolja, és ezt az üzenetet juttatja el egy adott csatornán (például sajtó, rádió, televízió) a célközönségnek, 
akik dekódolják, felfogják a saját szűrőik által átalakított módon. A célközönség vagy verbálisan, vagy cselekedeteivel reagál.

2. ábra

A válságkommunikációs folyamat elemei ${ }^{7}$

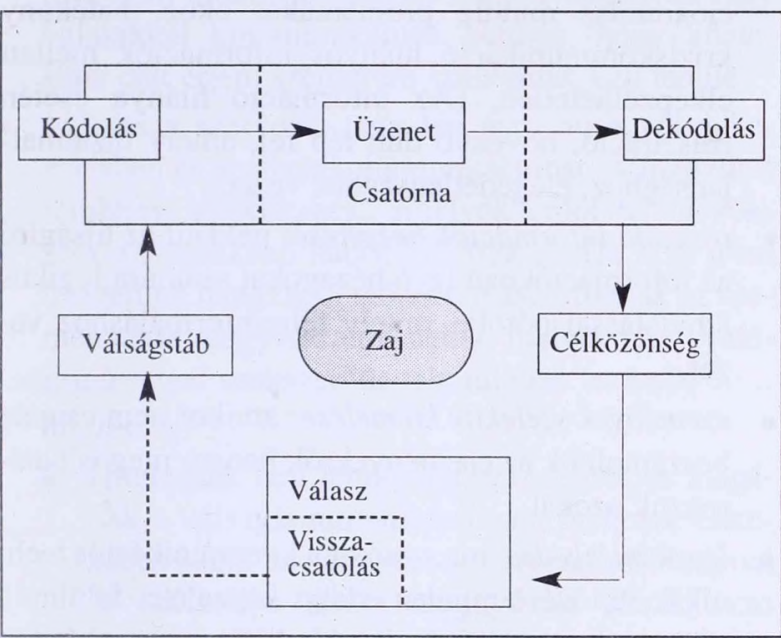

A kommunikációs folyamat egyrészt a szervezeten belül, másrészt kifelé zajlik. Amíg az üzenet eljut a közlőtől a befogadóig, különböző szűrőkön megy keresztül (3. ábra).

\section{Külső kommunikációáramlás}

3. ábra

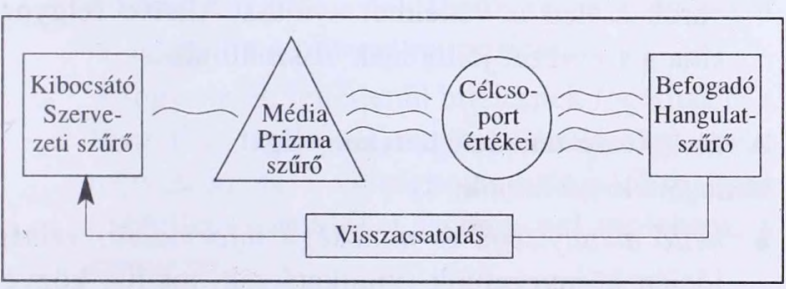

A szürők hatását erősítő és gyengítő tényezők:

- a szervezeti szektor esetében a történelmi és jelenlegi hitelesség,

- a média esetében az elfogultság jellege, a médium fajtája, az idő és hely, valamint a relevancia és a kontextus a meghatározó,

- a célcsoport értékei, vagyis az elfogultsági szűrőt befolyásoló értékek: a földrajzi, gazdasági státus, a szociális státus, a kultúra, a faj/eredet, az oktatás és a korábbi kapcsolat a küldővel,

- a befogadóra, amit hangulati szűrőnek is nevezünk, hatással van jelenlegi fizikai, érzelmi és érzékelési állapota (4. ábra).

\section{Belső kommunikációáramlás}

4. ábra

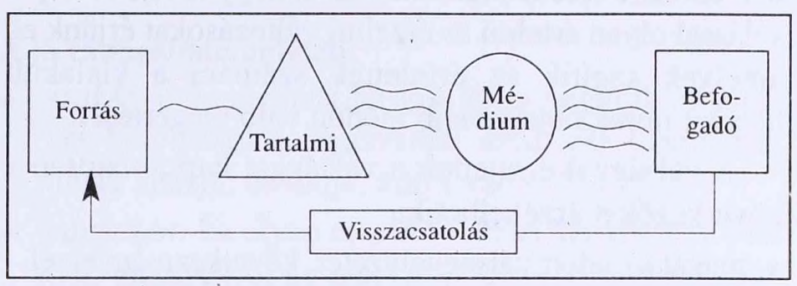

A forrás tulajdonképpen a személyes hitelesség szûrője, amit alapvetően a közlő személye (ki vagy?), tapasztalata, az iránta érzett bizalom határoz meg. Az üzenet tartalmi szűrője - amiről szó van. A médiumszûrő a küldés módszerét jelenti, míg a befogadó elvárásait elsősorban az befolyásolja amit hallani akar, ami a szervezetről alkotott nézete és személyes benyomása (5. ábra).

5. ábra

\section{A kommunikációs folyamat hatékonysága ${ }^{8}$}

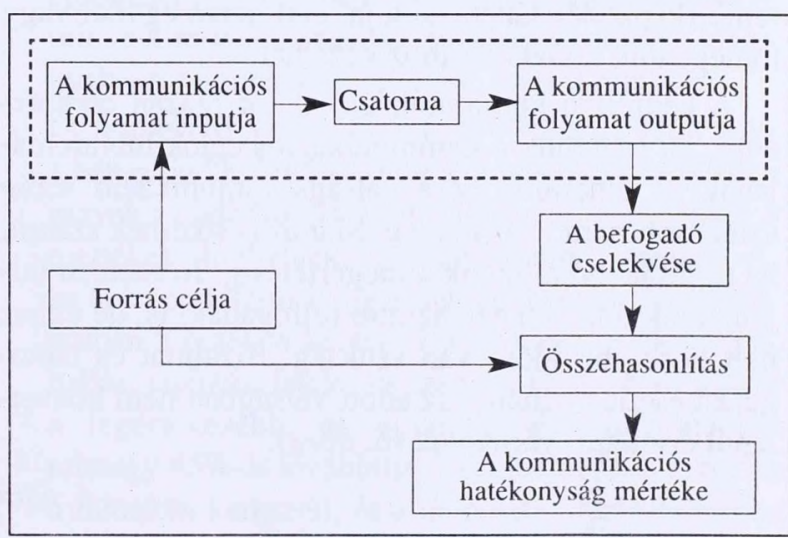

Általánosságban elmondhatjuk, hogy a kommunikáció hatékonyságát az üzenet befogadójának viselkedésváltozásán tudjuk lemérni. Legfőbb kritériuma az a befolyás, amit a közlést adó személy a közlést felvevőre tud gyakorolni. A befolyás azonban nem kontrollt jelent. Azt jelenti, hogy a közlést adó eléri a kívánt eredményeket. Ha a forrásnak az a szándéka, hogy megváltoztassa valakinek a viselkedését, akkor nem elég azzal mérni a kommunikációs hatékonyságot, hogy mennyire értette meg a befogadó azt, amit a forrás közölni akart. Lehet, hogy a befogadó tökéletesen megértette a forrás üzenetét, mégis ugyanúgy viselkedik továbbra is, ahogyan eddig viselkedett. Az ilyen kommunikációs kísérlet kudarcot vallott mind a forrás, mind a befogadó szempontjából. A válságkommunikáció során az érzelmeknek, az attitűdöknek 
meghatározó a szerepe - a média mellett -, amely jelentősen befolyásolja a kommunikáció hatékonyságát. Ennek ellenére törekednünk kell arra, hogy tudati befolyásolással olyan értelmi és érzelmi változásokat érjünk el, amelyek segítik az érintettek számára a kialakult helyzet minél objektívebb módon való megértését.

A válsággal érintettek a válsággal kapcsolatosan a következőket érzékelhetik:

- magát az adott válsághelyzetet, következményeivel,

- a válságkommunikációval eljuttatott üzeneteket, és a

- a más forrásból származó híreket, véleményeket.

A válsághelyzetben az érintett emberek által tapasztaltaknak összhangban kell lennie a válságkommunikáció során elhangzottakkal. Ezzel csökkenthetjük a válság közvetlen káros hatásait, és megelőzhetjük, illetve semlegesíthetjük a más forrásokból (kollegáktól, beszállítóktól, konkurenciától, tömegtájékoztatási eszközöktől stb.) származó híreket. Ha a válsággal érintettek bizonytalanságérzése információhiánnyal, hamis információkkal párosul, beindulhat a rémhírképződés láncreakciója, ami aztán egyéni vagy tömegpánik kialakulásához vezethet.

A kétirányú kommunikáció akkor igazán eredményes, ha feljutunk a kommunikációs célok hierarchiájának ${ }^{9}$ a csúcsára. Ez a válságkommunikáció során szinte sohasem valósul meg. Már az is sikernek számít, ha rövid távon eljutunk a megértetésig. Jó esetben feljuthatunk a következő szintre (elfogadás) is, de ehhez már hosszabb időre van szükség. Bizalmat és támogatást esetleg néhány, az adott válságban nem közvetlenül érintettől várhatunk (6. ábra).

6. ábra

A kommunikációs folyamat hierarchiája

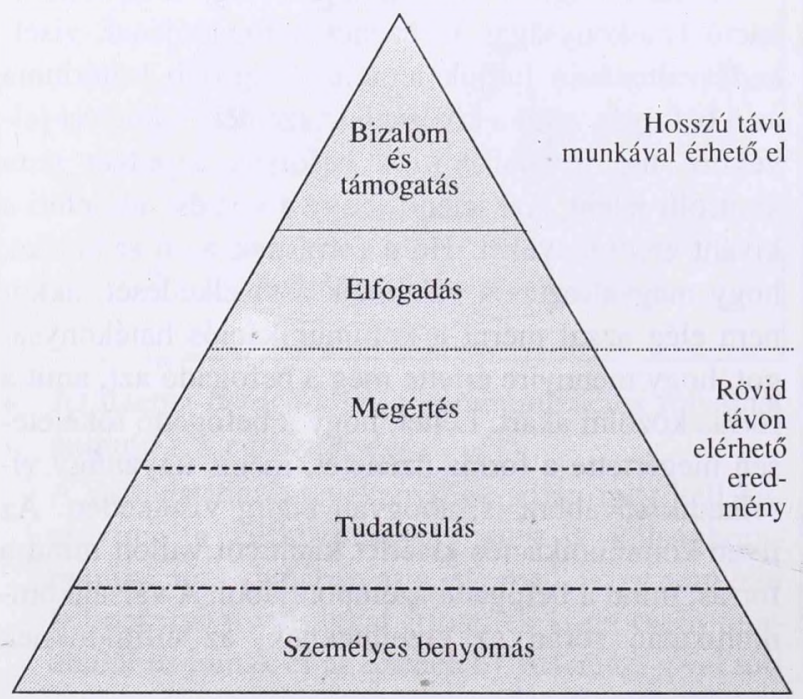

A hatékony válságkommunikáció ellen ható tényezők:

- felkészületlenség egy esetleges válságra: meglepetésként ér bennünket, úgy gondoljuk, hogy velünk ilyen nem történhet,

- akut információhiány: válság esetén az információáramlás mindig problémákat okoz, hatékony kríziskommunikáció hiányos információk mellett elképzelhetetlen, (Az információ hiánya esetén frusztráció, növekvő düh lép fel, amely bizalmatlansághoz, elégedetlenséghez vezet.)

- pszeudo információk beépitése: például az újságíró az információkban levő hézagokat számára logikus áthidalással pótolja, amely félreinformáláshoz vezet,

- események szelektív kiemelése: amikor nem csupán beszámolunk az eseményekről, hanem meg is határozzuk azokat,

- lassú intézkedés: ma, amikor a kommunikációs technikák fejlődése minden eddigi képzeletet felülmúl, pillanatok alatt terjednek a hírek, ez a rossz hírekre pedig hatványozottan igaz. Valójában időben csak akkor tudunk intézkedni, ha nem utólag reagálunk, hanem megelőzzük a vállalat kiegyensúlyozott müködése ellen ható ,pletykákat”. Az a vállalat, amelyik rendszeresen tájékoztatja ügyfeleit, kellő információval látja őket, az esetleges minőségi problémákat nem kimagyarázza, hanem megoldja, olyan imázst teremt, amely a bekövetkező egyensúlyi zavarok esetén is védelmet nyújthat, illetve felgyorsítja a szervezet jó hírének visszaállítását.

\section{A válságkommunikáció hatékonyságát} támogató kritériumok:

- kellő mennyiségü és minőségü információ: válság idején környezetünk (munkatársak, média, közvélemény, ügyfelek, versenytársak stb.) viselkedése megváltozik. A munkatársakon kezdetben az aggodalom, ha súlyosabb a válság a gyász lesz úrrá. Ebben a helyzetben nagyon fontos szerepe van az információnak, hogy biztonságban érezzék magukat és ellensúlyozzuk a pletykákat, a spekulációt.

- pontos helyzet-és folyamatfelmérés: olyan információgyűjtő és információelemző tevékenység, amely a szervezet belső és külső viszonyainak feltárását szolgálja,

- gondosság, odafigyelés: például az ügyfelek aggódni kezdenek a szolgáltatás vagy a termék szállítása miatt, ezért egyből meg kell keresni őket, ezzel jelezve, hogy odafigyelünk rájuk, 
- kompromisszum: szerencsésebb esetben konszenzus,

- elkötelezettség,

- kreativitás: a felső vezetéstől független megoldás,

- célközönségre szabottság: fontos a válságkommunikációban résztvevők körének figyelembevétele, hisz nem általában, hanem mindig valakivel vagy valakikkel kommunikálunk. Ahhoz, hogy közlésünk célt érjen, személyre szabottnak kell lennie,

- idő: ha a szervezet nem lép gyorsan a válságkezelésben és a válságkommunikációban, felnagyított rémhírek keletkeznek, amelyek cáfolataival sokszor az ellenkező hatást érhetjük el. Ha nem a mi üzenetünk hangzik el először, mások fognak az eseményekre magyarázatot találni, melyek nagy valószínűséggel szakszerűtlenek, túlzóak lesznek,

- hitelesség:

- Hitelesnek kell lennie a szervezetnek és magának a válságkommunikációnak, melynek elérésében segít, ha nem akar a szervezet közvetlenül és erőlködve direkt meggyőzést elérni, nem akarja az álláspontját ráerőltetni a befogadókra, a fogyasztókra.

- A hitelességet kifejezetten erősíti, ha a szervezet közvetíti azokat a dolgokat is, amelyek a szervezet érdekei ellen hatnak, de valós részei a kialakult válsághelyzetnek. Pl. egy termékkel kapcsolatos olyan rejtett minőségi problémák nyilvánosságra hozatala, amit a fogyasztók még nem ismertek fel. Az igazmondás a kommunikáció hitelességének fontos része, még akkor is, ha rontja a pillanatnyi pozíciót.

- A fogyasztók feltétlenül hitelesnek fogadják el a független, szakértői megnyilvánulásokat, ezért nagyon jó, ha a válságkommunikációban ilyen független szakértőket is meg tud szólaltatni a szervezet.

- szabadidő: időnként ki kell lépni a körből, hogy később ráleljünk a jobb megoldásra,

- mindenki számára érthetö megfogalmazás, (KISS keep it simple stupid)

- közös szótár: egyazon jelenségre külön kifejezések használata lassíthatja, nehezítheti a megoldást,

- jó csatornaválasztás: a média szerepét a válságkommunikációban nem lehet túlértékelni. A válságban érintettek nagy többsége számára azok az események történnek meg és úgy, ahogy a média közvetíti.

- elöre kidolgozott kommunikációs terv: a sikeres válságkommunikáció talán legfontosabb kritériuma, hogy a válságkezelés még a válság bekövetkezte előtt megkezdődjön. A terv pozíciókra bontva tar- talmazza a feladatok pontos meghatározását. A kommunikációs csatornák előre történő kiépítését, ami a probléma jelentkezésekor azonnal igénybe vehető.

\section{A jó válságkommunikátor}

- szakértő: ésszerünek látszik, hogy hagyjuk magunkat befolyásolni olyasvalaki által, aki megbízhatónak látszik, és tudja, miről van szó,

- pártatlan: ha olyan érzelmi töltésű kérdésekről van szó, amelyekről az emberek véleménye eltérő, valószínűleg nem lehet olyan közlést szerkeszteni, amelyet mindegyik fél egyformán pártatlannak fog megítélni, mégis meg kell próbálni,

- érzelemmentes: nem létezhet olyan szörnyú helyzet a kommunikátor számára, amelyben elveszthetné az érzelemmentességét, különben az események elsodorják,

- hiteles: amikor a testbeszéd összhangban áll azzal, amit mondunk, az alátámasztja szóbeli kommunikációnkat. Amikor nincs összhangban szóbeli kommunikációnkkal - akár ellent is mondhat neki -, az eredmény az lesz, hogy a testbeszéd hatása nagyobb, mint a kimondott szavaké, hiszen az emberek könynyebben hisznek a szemüknek, mint a fülüknek.

(A testbeszéd a közlés mintegy 70\%-ának felel meg, a hangszín kb. 20\%-ot, míg a ténylegesen kimondott szavak mindössze $10 \%$-ot jelentenek. Bár a pontos mértékek eltérhetnek, az arányok aligha meglepőek, ha belegondolunk, hogy az agyunkat érô információk csupán 5 érzéken keresztül jutnak el - ezek a látás, hallás, tapintás, ízlelés és szaglás. Ezek közül a látás a legértékesebb, az agyunkat érő információk mintegy $85 \%$-át továbbítja. Körülbelül $10 \%$ kerül be a fülünkön keresztuil, és a fennmaradó három érzékszerv képviseli a maradék 5\%-ot).

- megfelelő a stílusa: ugyanaz a tartalom különböző stílusban előadva más hatást vált ki a hallgatóságból. A témának, az eseménynek, a helyszínnek, a befogadóhoz való viszonynak és a megválasztott stílusnak összhangban kell lennie.

- szimpatikus a személye és a viselkedése,

- megbízható: ha valaki nem nyerhet azzal, ha meggyőz bennünket, hajlamosabbak vagyunk hinni neki.

A (jó) válságkommunikáció ${ }^{10}$ az a folyamat, amikor egy szervezet:

- egy számára hátrányos, súlyos, sokszor váratlan helyzetben,

- tudatosan és előre megtervezetten,

- a ténylegesen bekövetkezett állapotnak megfelelően (tényszerúen), 
- a korábbi eredményekre építve,

- kommunikációs kapcsolatrendszerét a leghatékonyabban működtetve,

- a célközönség elvárásait és érdekeit is figyelembe véve,

- a vállalat adott céljának (a válság elhárításának) elérésére, és a következmények pozitív befolyásolására törekszik.

Problémák nap, mint nap adódnak, de sokszor leértékeljük azokat. A válság hasonlít a betegséghez, ha időben észrevesszük a figyelmeztető jeleket, elkerülhetjük, hogy súlyossá váljon a helyzet. Viszont, ha nem kezeljük, elburjánzik, és az egyébként egészséges részeket is megfertőzi a kór. Ezért a felkészülés, a folyamatos külső és belső helyzetelemzés önmagában is esélyt adhat bizonyos válságok elkerülésére. Ha mégis bekövetkezik a baj, a válságkezelés és a kommunikáció lényegi eleme, hogy ne értékeljük le a kérdést, és időben olyan magatartást tanúsítsunk, amely lehetetlenné teszi a válság továbbfejlődését. A szervezetek azonban gyakran ignorálják a probléma létét, vagy magától várják a megoldást. A cégvezetés viselkedése nagyban befolyásolja azt, hogy a probléma eszkalálódik-e. Vigyáznia kell arra, hogy a bizalmi olló mennyire nyílik meg, s a menedzsment mennyire válik hiteltelenné. Ezért jobb a rosszat őszintén közölni, mint szépíteni vagy elhallgatni. A pletyka, az elferdített, hiányos információ több bajt okozhat, mint a rossz hír.

Az utóbbi időben divatossá vált szlogent „válsághelyzetben tilos hallgatni" úgy fogalmaznám át: elkerülhetjük a nagyobb egyensúlyi zavarokat, ha már azok kialakulása előtt is fontosnak tartja a vállalat, hogy állandóan informálja a vele kapcsolatban állókat. Esetleges válság esetén már nem tud kialakulni az adott szervezetbe vetett bizalom, ha előtte sem volt meg. Tehát nem csak válság alatt, de már előtte is tilos hallgatni.

\section{Felhasznált irodalom}

Aronson, E. (1994): A társas lény. Közgazdasági és Jogi Könyvkiadó, Budapest

Balai Róbert - Szatmáriné Balogh Mária (1997): Önismeret, kommunikáció, csoportjelenségek dióhéjban. Olvasókönyv a kommunikációs tréningek résztvevôii számára. Külkereskedelmi Főiskola, Budapest

Bodor Pál (1998): Hierarchikus játék. Médiakönyv, ENAMIKÉ

Fearn, K. - Banks (1996): Crisiscommunications, a casebook approach Lawrence Erlbaum Associetes Publishers, Mahwah, New Jersey
Fekete Ferenc - Sándor Imre (1997): Válságkezelés és kríziskommunikáció. Budapesti Közgazdasági Egyetem, Budapest

Hill - Knowlton (1995): Válságkezelés és kommunikációs tréning. Jegyzetek

Kocsis József (1994): Változások menedzselése. Műszaki Könyvkiadó, Budapest

Mastenbroek (1991): Konfliktusmenedzsment és szervezetfejlesztés. Közgazdasági és Jogi Könyvkiadó, Budapest

Németh Márta (1998): A public relations elmélete. Külkereskedelmi Főiskola, Budapest

Noszkay Erzsébet (2003): A lehetôségek és veszélyek határmezsgyéjén mozogva... (...avagy a változások kezelői miért nem nélkülözhetik a válságmenedzsment szemléletét és technológiáját ...?!) Miskolci konferencia, 2003 május

Noszkay Erzsébet (2002): A válságmenedzsment és hazai gyakorlata, Szent István Egyetem Gazdaság- és Társadalomtudományi Kar Vezetô- és Továbbképző Intézet, Budapest

Noszkay Erzsébet: Homeopátiától a sebészkésig... II. Országos Tanácsadói Konferencia, 2003. április 24., szerzői anyag

Rácz Gábor (1996): Nagyvállalati krízislehetőségek és válságkezelési stratégiák a magyar dohányiparban, Doktori értekezés, BKE, Budapest

Rivers, W. L. - Mathews, C. (1993): Médiaetika, Bagolyvár Könyvkiadó, Budapest

Válság- (katasztrófa) kommunikáció. (1996): Tanulmányok és szemelvények. Petit Real Könyvkiadó, Budapest

Válságkommunikáció, ahogy a legjobbak csinálják, http://www.menedzsmentforum.hu/cikkek/tanulmany.php?arti cle $=869 \&$ page $=1$

\section{Lábjegyzetek}

1 Noszkay Erzsébet (2000): A válságmenedzsment és hazai gyakorlata, Szent István Egyetem Gazdaság- és Társadalomtudományi Kar Vezetô- és Továbbképző Intézet, Budapest

2 Fekete Ferenc - Sándor Imre (1997): Válságkezelés és kríziskommunikáció, 25. oldal, a Budapesti Közgazdasági Egyetem

3 Válság- (katasztrófa) kommunikáció. Tanulmányok és szemelvények. Petit Real Könyvkiadó, Budapest, 1996

4 Hill - Knowlton (1995): Válságkezelés és kommunikációs tréning. Jegyzetek alapján.

5 Válság- (katasztrófa) kommunikáció. Tanulmányok és szemelvények. Petit Real könyvkiadó, Budapest, 1996

6 Válság- (katasztrófa) kommunikáció. Tanulmányok és szemelvények. Petit Real könyvkiadó, Budapest, 1996

7 Válság- (katasztrófa) kommunikáció. Tanulmányok és szemelvények. Petit Real könyvkiadó, Budapest, 1996

8 Barlai Róbert: Balai Róbert - Szatmáriné Balogh Mária (1997): Önismeret, kommunikáció, csoportjelenségek dióhéjban. Olvasókönyv a kommunikációs tréningek résztvevői számára. Külkereskedelmi Fôiskola, Budapest

9 Németh Márta (1998): A public relations elmélete, Külkereskedelmi Főiskola, Budapest

10 Zsebők Lajos: Válságkommunikáció a víziközmû-szolgálatában, http://www.vizugy.hu/vizugy.nsf/0/b80b3bd532165c24c1256c8 500380c0e? OpenDocument. 